\section{US State Department hires consultant to boost role of science}

Washington

The US Department of State announced last week that it will employ Jack Gibbons, former science adviser to President Bill Clinton, as a consultant to help guide its consideration of a critical report from the National Research Council (NRC) on its understanding and use of science.

The report, which reflects pressure from both the scientific community and Congress, calls for extensive changes in training and organization to boost the role of science and technology in US foreign policy. The department's move is seen as a commitment to achieve this.

Madeleine Albright, the secretary of state, also promised to meet with Bruce Alberts, the president of the National Academy of Sciences, to discuss the report, as soon as her schedule permits. Alberts first asked for such a meeting a year ago.

The State Department has promised many times to address accusations that it ignores science, but changes have been slow in coming. For example, senior officials have pledged twice in the past two years that a senior scientific adviser would be appointed, but no such appopintment has been made.

The drive for reform seems to have gained new impetus after the Senate passed a foreign-relations bill requiring the department to appoint a science adviser and to report back to the Congress on how it plans to implement the NRC's recommendations. The bill is expected shortly to becomelaw.

The NRC says the State Department should train all foreign-service officers and diplomats to give them "basic competence in scientific, technological and health matters", and that it should appoint 25 scientifically qualified senior diplomats at its foreign embassies.

But Glenn Schweitzer, the director of the NRC study, says its most important recommendation is that the secretary of state should establish a science and technology policy, together with an "action agenda" to implement it.

"We're pleased that the committee has done such a thorough job," says Ken Brill, acting assistant secretary for oceans, environment and science at the State Department. Brill says the department is facing "a new set of issues, many of them science-based" and that it plans to respond to the challenge. Gibbons, he says, will help the department come up with a science adviser's position "that will be effective".

Colin Macilwain

\title{
Varmus announces decision to quit NIH for cancer centre
}

\section{Washington}

Harold Varmus, director of the US National Institutes of Health (NIH), announced last week that he will resign at the end of the year to become president of the Memorial Sloan-Kettering Cancer Center in New York.

Varmus's six years in office have seen a remarkable expansion in NIH's budget from just over $\$ 10$ billion to almost $\$ 16$ billion - and something of a renaissance in the scientific reputation of the institute's intramural programmes.

He claims that "the whole enterprise is a happier and a stronger place" than when he arrived, partly because of the budget but also because of the people he has recruited.

Varmus's letter of resignation to President Bill Clinton called on the president "to consider other active medical scientists" in the search for a successor.

Varmus, who won the Nobel prize for physiology and medicine in 1989 with Michael Bishop for his work on retroviral oncogenes, says his top priority in New York will be "bringing basic science together with the clinical researchers". He intends to strengthen some areas of research, including cancer genetics, and to collaborate with other New York medical centres.
During his tenure at NIH, Varmus developed a knack for preventing difficult issues, such as embryo research, from disrupting the agency's ties with the Congress. He also maintained excellent relations with Capitol Hill after Republicans assumed control of both houses of Congress in 1995.

Ruth Kirschstein, NIH deputy director and a long-time NIH administrator, will take over as acting director while a search committee seeks a nominee to replace Varmus.

With the presidential elections due next November, it may prove difficult for Clinton and Donna Shalala, the health secretary and Varmus's immediate boss, to find a suitable replacement. Any appointee would have to be confirmed by the Republican-controlled Senate, and be prepared to work for a new health secretary in a new administration, Democrat or Republican.

This may make the position unattractive to an outsider in the Varmus mould, and early speculation has focused on top scientific administrators already at NIH who have good political connections with both parties. These include Tony Fauci, director of the National Institute of Allergy and Infectious Diseases, and Richard Klausner, head of the National Cancer Institute. Colin Macilwain

\section{Japan plans to join array project}

Tokyo

Japan is planning to become the third partner of the Atacama Large Millimeter Array (ALMA), an international project currently led by US and European astronomers to build a large millimetrewave observatory at a mountain site 5,000 metres high in Chile's Atacama Desert.

The collaboration would be based on a joint framework discussed during a meeting in Washington last week, at which ALMA partners and Japanese astronomers explored scientific aspects of the project.

Riccardo Giacconni, the president of Associated Universities Inc., which operates the US National Radio Astronomy Observatory (NRAO) - responsible on behalf of the National Science Foundation for the US end of ALMA — says that Japan's involvement would create "the world's first truly global astronomical collaboration".

At a meeting in Tokyo two weeks ago, the three partners discussed scientific and technological aspects of the planned collaboration and agreed that merging ALMA with Japan's planned Large

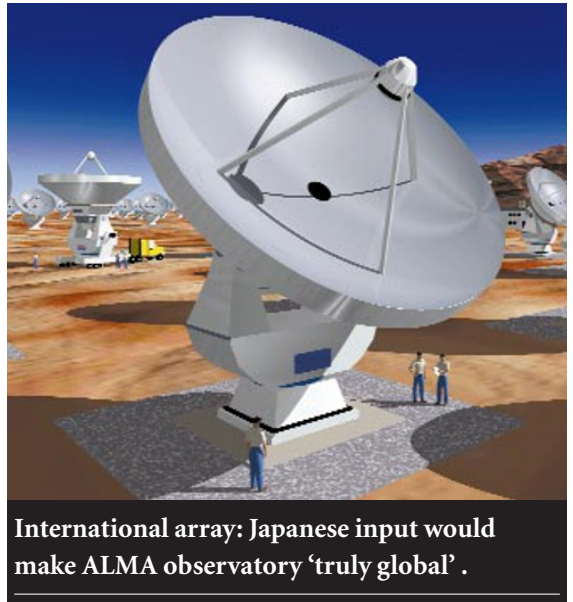

Millimetre and Submillimetre Array (LMSA) would lead to a better, more sophisticated facility.

An agreement was signed in Washington in June by US and European representatives to continue collaboration on the first phase of the telescope, which will image the Universe at millimetre wavelengths, between the radio and infrared spectral regions. It is 
hoped that full approval for the project will be obtained by 2001, with limited operations starting in 2005, and that the array will be fully operational by 2009 .

Keiichi Kodaira, director-general of Japan's National Astronomical

Observatory (NAO), which oversees LMSA, argues that Japan's involvement will bring substantial benefits to the project. "Since LMSA is already in the advanced stages of its design and development phase, there is much that Japan could contribute to the development of ALMA," says Kodaira.

But he says that Japan would not be able to join ALMA as an official partner until it can secure the necessary funding from the Ministry of Education, Science, Sports and Culture (Monbusho), which oversees NAO.

"One of the problems is the fact that we have a very different funding system from that of US and European research institutes," says Kodaira. "Since the budget request for next year has already closed, we hope to secure relevant funding after the merger of Monbusho and the Science and Technology Agency (STA) in 2001."

Until then, LMSA and ALMA are expected lead a separate existence, although the three sides have agreed on Japan's early involvement in the project at a scientific and technological level. Negotiations are currently taking place to add Canada to the US team, and Spain to Europe's participation.

Kodaira says that Japan will participate in the design and development phase of ALMA, including the investigation of the site.

Last week's meeting included discussions on the design differences between LMSA, which was planning to build 50 ten-metre antenna dishes, and ALMA, which plans to build 64 telescopes with 12-metre antennas. The purpose of the meeting was "to plan how to maximize ALMA's scientific potential", says Paul Vanden Bout, director of NRAO.

ALMA, whose members also include the European Southern Observatory, France's Centre National de la Recherche Scientifique and the United Kingdom Particle Physics and Astronomy Research Council, is to study the structure of the early universe, the formation of the stars and the evolution of galaxies.

Kodaira hopes that ALMA will change the general perception in Japan that astronomy has no practical applications. He says that research into millimetrewave interferometry could lead to new technologies in telecommunications, information technology and semiconductors, all priority areas in next year's budget. Asako Saegusa \& Natasha Loder

\section{Aim for better business sense to bolster Russian science}

Moscow

The Russian Academy of Science (RAS) has set up a new body, known as the AboveBudget Foundation (ABF), to manage its property and channel the income it receives to supporting scientists and their work.

According to Gennady Mesyats, the academy's vice-president responsible for $\mathrm{ABF}$ activities, the new body has already generated more than \$1 million in income, even though it started operating only a few months ago.

"Next year we hope to get $\$ 3$ million, and in the coming years ABF plans to operate with tens of millions of dollars," says Mesyats. "We hope that this will enable our libraries to subscribe to all major journals, and that we can finance expeditions, and solve our most acute financial problems."

Mesyats told a meeting of the academy's praesidium in Moscow last week that, for the first time in recent years, the government has this year transferred all the money it had allotted to science both on time and in full. But the praesidium emphasized that the total amount being made available is still insufficient to meet the needs of Russian science.

External income is therefore very important, Mesyats emphasized, particularly given that the budget money can only be used for specified purposes, such as salaries, and cannot be redistributed. The academy owns considerable property, which until recently has been inefficiently used. It has 38 buildings in Moscow alone, and many stores, hotels and other real estate around the country.

The academy also receives income from its scientific ships, and substantial revenue is raised through its international academic association 'Science', which manufactures

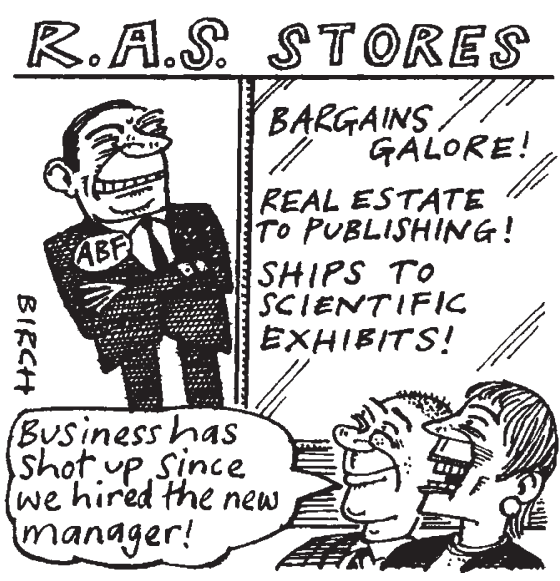

and distributes copies of scientific exhibits.

The academy also makes money from publishing. More than 80 scientific journals are published in English by a recently founded publishing company, Nauka, which is expected to raise \$1 million next year, partly because publication of the two leading Russian physics journals was transferred to it from the American Institute of Physics.

The ways in which these funds are to be spent are discussed at weekly meetings of the RAS praesidium, chaired by Yuri Osipov, the academy's president. This year's priorities have included buying apartments for young scientists, providing petrol supplies for mountain observatories and supporting scientists' widows.

"Finding external funds is a new activity for us, even though in other countries it is quite normal; up to 30 per cent of the income of US universities comes from using their property, such as stadiums, parking places and living quarters," says Mesyats. Carl Levitin

\section{Anger at Israeli sex crimes DNA bank}

Jerusalem

Israeli police have been accused by the Association for Civil Rights in Israel of illegally taking DNA samples from suspected sex offenders in their search for a serial rapist.

The police have taken saliva samples from previous suspects in other sex cases, even though they are not believed to have any connection with the serial rapist, who has attacked women in the Tel Aviv region during the past year. The samples are being used to produce DNA profiles for a police data bank.

But Dan Yakir, the counsel for the civil rights association, has written to Israel's attorney-general, Elyakim Rubinstein, claiming that this activity is "manifestly il- legal" and "seriously violates the fundamental rights to freedom, privacy, and respect". $\mathrm{He}$ adds: "The police have no authority to summon for investigation a person against whom there is no specific suspicion."

Yakir also argues that the establishment of a DNA data bank on sex offenders is illegal without legislation on this. But a spokeswoman for the Ministry of Internal Security says DNA samples are taken only with subjects' written consent. She acknowledges that the samples are being taken not only to find the serial rapist, but also to "advance the investigations of other rapes". But she argues that the samples benefit those who give them by clearing them of the crimes. Haim Watzman 